\title{
Kulturní a sociální dějiny pracovního prostředí do roku 1950
}

\author{
BOHUSLAV ŠALANDA*
}

Cultural and Social History of Work Environment to the Year 1950

\begin{abstract}
Work environment theory has always been straddled between various sciences and their sub-disciplines; to some extent there is a certain "nomadicity" in this field. Generally speaking, during his development man has been exposed to the pressure of the environment, not only natural but also the "artificial" one, in this case work evironment or "residential" issues (so-called housing issue). Furthermore, the entire historical situation was also influenced by industrial production with its factory halls. People (male and female workers) had to find their position in this surroundings. The presented sketch deals as well with the hygiene of work and the occupational diseases. The development of technocratic tendencies is also taken into account.
\end{abstract}

Keywords: working environment; industrial production; hygiene of work; housing issue; technocratic trends

DOI: $10.14712 / 23363525.2021 .8$

\section{Úvod}

Předloženou skicu nelze číst jako vyčerpávající a kompletní přehled. Uplatňuje se v ní vedle řady jiných souvislostí i subjektivní výběr priorit či přidružených myšlenkových rámců. Teorie pracovního prostředí, techniky a technologií byla vždy rozkročena mezi různými vědami a jejich dílčími disciplínami; svým zpơsobem na tomto poli funguje jistá „nomadičnost“. Obecně řečeno, člověk je během svého vývoje vystaven tlaku prostředí nejen př́rodního, nýbrž také toho „umělého“, v našem případě pracovního, popřípadě „sídelního“ (tzv. bytová otázka). Dále na celou historickou situaci zapůsobila též průmyslová výroba se svými továrními halami; člověk (dělník nebo dělnice) tu musel nalézt vlastní místo, avšak často mu bylo takové zařazení jen přiděleno.

Hlavní záměr, s nímž k přítomnému skicování přistupuji, spočívá v rozhodnutí pokusit se v naznačeném směru nalézt nějaké volné místo pro nové bádání. Jak uvidíme, některá témata jsou již podrobně probrána a zmapována. Pokud jde o zdroje, jeví se slibnou návaznost na fondy Národního technického muzea v Praze. Ve hře zůstává také řada bibliografií a dalších pramenů, popřípadě se lze opřít o publikace ze starší doby; ty ale představují zdroje, ke kterým je obtížné se dostat: bud' nejsou snadno dostupné, nebo jsou ztracené.

Ovšem hlavní inspirací pro tuto skicu bylo studium pojednání starších sociologů, z nichž je třeba v první řadě uvést Emanuela Chalupného [1941]. Zejména musíme věnovat pozornost jeho dílu Práce a jiné činnosti, pojednávajícím o práci jako sociálním jevu, a to v protikladu k zábavě. Chalupný akcentuje „kulturní činnost záležející ve více méně

\footnotetext{
* Doc. PhDr. Bohuslav Šalanda, CSc., Pracoviště historické sociologie Fakulty humanitních studií Univerzity Karlovy, Pátkova 2137/5, 18200 Praha-Libeň. E-mail: bohuslav.salanda@fhs.cuni.cz
} 
pravidelném, úmyslném, účelovém vynaložení energie, jejíž účinek záleží na subjektivně v námaze nebo únavě, objektivně ve vytvoření užitečných produktů“. Fenomén práce studuje autor opravdu „zgruntu“; začíná u nativních etnik, kde práce mohla být spojena s volným časem, navíc usnadněna rytmickými písněmi třebas při veslování nebo stloukání sága. Chalupný nezapomíná ani na „práci na běžícím pásu“, přičemž „pracovní děj“ se v takovém kontextu dělí na jednotlivé, časově ohraničené činnosti. Jedná se vlastně o jakési „mechanické nucení k výkonu“. Vysvětluje se tu taktéž, že tento typ pracovních úkonů prosazoval především Henry Ford a u nás Tomáš Bata ${ }^{1}$. Bat’a nadto razil různá pracovní hesla, dbal na životní podmínky „svých“ lidí, např́íklad stavbou bytových domů apod. Proslulou se rovněž stala jeho cenová politika. Chalupného postřehy se týkají mnoha podobných témat, kupř́kladu „Zotavení pracovníků (rekreace) jako nutná protiváha práce“ [1941: 168-173]. Ve shromažd’ování dalších charakteristik a citací z jeho pozoruhodné knihy by jistě bylo možné pokračovat, pokročme však dále.

V knihovně badatele na pracovním poli by neměla chybět Sociologie sedláka a dělníka (Praha: Orbis 1937) Inocence Arnošta Bláhy. Autor tu podává určitou společenskou typologii spojenou s prací, dále postihuje povolání jedince, jeho typické pracovní a jiné rysy apod. Podle Bláhy (c.d., s. 11) „každá pracovně odlišná skupina společenská má svůj profil, svého ducha své výrazné reaktivní gesto“. Mimochodem - sociologický seminár Masarykovy univerzity se zabýval studiem vrstvy dělnické, selské a inteligence. Za tímto účelem byla vytvořena kolekce sta dělnických biografií. Nemělo by nám přitom uniknout, že už od konce 19. století se podstatně zvýšil počet různých povolání, a to i v oblasti dělnické práce.

Přední český sociolog dále vysvětloval: „Se zřetelem k vlastnictví výrobních prostředků náleží tedy dělník do oné pracovní a společenské vrstvy, jež nemá svých prostředků výrobních“ [1937: 26] Jinak materiálně pracující rolník, řemeslník, částečně i obchodník pracují „na svém a ve svém“, navíc vlastními výrobními prostředky. Podle tehdejšího Bláhova názoru nemají široké vrstvy dostatek životního minima; přirozeně se počítá s diferenciací uvnitř dělnického stavu. Naproti tomu střední vrstvy úřednické svůj vzestup uskutečňují mnoha různými způsoby, např́íklad včetně sňatků.

\section{Sociální inženýrství, zdatnost a výkonnost}

Od počátku 20. století se nově brala $\mathrm{v}$ potaz problematika sociálního charakteru hospodářství, které se neobejde bez znalostí praktické psychologie (psychotechniky). Do hry tak vstupují i znalosti pracovní hygieny (sociální profylaxe), ale take poznatky o moderním způsobu bydlení, osídlování apod. Industrializace by se měla nadále obejít bez patriarchalismu či paternalismu; mimo jiné se též počítá s vedením úrazové statistiky a chorobami z povolání. Terminologicky se začíná psát o „technokracii“ - technické výdobytky postupně zcela proměňují tvářnost hospodářství. Přitom velmi zapůsobila technokracie americká, podle níž je nutno hospodářství zdokonalit, konkrétně změřit a zvážit, zjistit daný stav. Jinak řečeno nalézt metody, s jejichž pomocí by se provedla nejlepší syntéza všech možností.

1 Viz např́iklad publikace: Cekota, Antonín (ed.) [1935]. Zlín, město životní aktivity. Zlín: Nakl. Společnosti TISK. 
Pozoruhodným autorem pro studium industriální racionalizace a zrychleného času je německý badatel Peter Borscheid [2007]. Borscheid se věnoval prostředkům, kterými lze docílit, aby se tzv. časová ekonomie stala druhou lidskou přirozeností. Doslova uvádí následující myšlenky: „Od konce 19. století se klade větší důraz na intenzivnější využívání času, tedy rychlejší práci a s ní související zkracování pracovní doby. K vyššímu pracovnímu tempu má zaměstnance motivovat systém odměn podle dosažených výkonů. Díky výrobně-technickým novinkám se tak zrychluje činnost strojů a celý výrobní proces se posouvá $\mathrm{k}$ automatizaci a přesnosti. Stroje s vyztuženými rámy dostávají silnější pohon a zdokonalená chladící mazadla stabilizují jejich chod a chrání je před nežádoucími účinky vysokých otáček" [2007: 281].

Pronikavé zkušenosti se od sedmdesátých let 19. století získávají při studijních cestách do Spojených států, kde se mladí nadějní muži setkávali s tamějšími průmyslníky a byznysmeny. Jednou z nejvlivnějších osobností se v té době stává Frederik W. Taylor, jenž postupně získává mimořádný vliv také v Evropě. V roce 1911 přichází se spisem Zásady vědeckého vedení podniku. Na přelomu století Taylor zavádí nové řezací stroje z tzv. rychlořezné oceli, dosahující dvojnásobné řezné rychlosti; v roce 1890 pak prosazuje tlakové mazání strojů. Proti nadměrnému tření se uplatňují kuličková ložiska - běží zkrátka o stále přesnější strojírenství. Ve všech směrech Taylor akcentuje racionalizaci, na dělníka pohlíží jako na stroj. Pohyby jsou speciálně koncentrované, jejich časový rozsah stanovený stopkami. Nic nezůstává bez povšimnutí v dělníkově pobytu na pracovišti, ve fabrice nebo $\mathrm{v}$ dílně.

Za pozornost stojí i názory Stuarta Chasea (1888-1985), ekonoma a sociálního teoretika; jeho myšlenky formoval mimo jiné Thorstein Veblen (viz níže). Chase píše o tehdejší strojové výrobě všeho druhu, od automobilů, traktorů, jízdních kol, psacích strojů, hodin apod. Stroje, kam oko pohlédne: motory, turbíny, dynama, žací stroje, popř́ípadě automatické váhy.

Strojová technika, respektive pásová výroba umožnila nejen výrobu velocipedů, nýbrž také automobilů. Stuart Chase [1931: 172] přibližuje způsob jejich výroby takto: „Pohyblivý pás na montování pohyblivých spodků u Forda se pohybuje (nebo vlastně se pohyboval při modelu T) šesti stop za minutu. Je na něm pětačtyřicet stanic či úkonů. Na stanici číslo jedna se na rám upevní blatníkové držáky, na stanici desáté se montuje motor. Dělník, který zastrkuje šroub, nedává naň matici, a dělník, našroubuje matici, ji nedotáhne. $\mathrm{Na}$ čtyřriatřicáté stanici se do motoru naleje benzin. Na čtyřiačtyřricáté vyjede hotový vůz do John Streetu.“

\section{Hygiena práce a nemoci z povolání}

V oblasti tzv. psychotechniky a jejího ekonomického významu, tj. organizace, řízení a racionalizace práce, se $\mathrm{s}$ prrihlédnutím k sociologickému kontextu konaly ve dvacátých a třicátých letech debaty a přednášky pořádané Masarykovou akademií práce. Jednalo se o vskutku mimořádné aktivity; nadto byla vydávána třísvazková Encyklopedie výkonnosti (Praha: Sfinx - B. Janda 1929-1933), do níž přispívaly tehdejší významné vědecké a politické osobnosti. V kapitole „Hygiena práce“ (1. svazek) se podrobně popisuje lidský organismus a jeho zdraví při práci. Autor kapitoly MUDr. Frank Svoboda [1929: 390] vysvětluje: „Hygiena práce vychází ze studia a výzkumu různých výkonů na lidský organismus 
a vlastností vniřních (fysiologie a psychologie práce), dále z poznatků, jakým způsobem ta která práce může poškozovati zdraví pracovníka (patologie práce) a za třetí, ze studií jak zabrániti poškození zdraví pracovníků v povolání a jak předcházeti kolektivně zdravotním risikům zaměstnání (sociální a veřejná hygiena práce).“

Z dostupných pramenů je zřejmé, že hygieně práce se věnovala pozornost již v 18. století, nebot’ se usuzovalo, že rizika v zaměstnání ohrožují hladký průběh práce - jedině zdravý pracovník je skutečně trvale výkonný. Shora zmíněný Frank Svoboda [1929: 398] upozornil rovněž na zevní vlivy práce na lidský organismus: „Pracovní prostor se svými atmosférickými podmínkami (mikroklima) má důležitý vliv na zachování zdraví a výkonnosti. Funkcionální význam je tím zřetelnější, když si uvědomíme, že dospělý dělník dlí třetinu celého dne v místě své práce a že i sebelepší konstituce je ohrožena sumací nejmenších škodlivých vlivů ve zkažené pracovní atmosféře."

V prvním svazku Encyklopedie výkonnosti se mimo jiné nachází zásadní kapitola „Nemoci z povolání“ (s. 425-443), jejímž autorem je profesor na pražské německé univerzitě MUDr. Julius Löwy (1885-1944). Löwy [1929: 425] hned na počátku poznamenává: „Ačkoliv první celistvé dílo o nemocích z povolání bylo vydáno Bernardem Ramazzinim již r. 1700, patří přece tento obor ještě dnes k nejnovějším medicinským disciplinám. Zvláště pokroky chemického průmyslu, technické vymoženosti, báňské stavby apod. v posledních desetiletích zvýšili u pracujícího jedince nebezpečí a donutili lékařskou vědu zabývati se intensivněji nebezpečím při práci a jeho důsledky - nemocemi z povolání. Onemocnění z povolání vyplývá z působení zaměstnání na lidský organismus.“

Právě Julius Löwy výrazně přispěl k utváření medicínského oboru pracovního lékařství a chorob z povolání. Jde o problematiku, která úzce souvisí s pracovní aktivitou člověka a rozšiřujícími se průmyslovými provozy. Velmi důležité a vyčerpávající informace k našemu protagonistovi přinesla v nedávné době Emilie Těšínská [2017]. Opravdu důkladně popsala jeho podíl na formování nového oboru pracovního lékařství, jež ve dvacátých letech také díky němu získalo institucionální podporu na půdě společnosti národů a Mezinárodního úřadu práce. Uved’me proto alespoň pár detailů ze života tohoto významného aktéra medicíny a medicínské vědy.

Julius Löwy se narodil 1. 5. 1885 v Karlových Varech v rodině lékaře Bernarda Löwyho; po rodičích byl německé národnosti a židovského vyznání. Löwy se ve dvacátých a třicátých letech intenzivně věnoval svému oboru, dne 25. 1. 1939 ale oznámil, že nebude na Pražské německé univerzitě dale přednášet; Ministerstvo vzalo jeho „žádost“ na vědomí „bez námitek“. Löwy pak náhle opustil Československo ohrožené nacistickým Německem stejně jako tehdy další členové pedagogických sborů židovského vyznání. K závěru jeho života v emigraci bohužel nejsou k dispozici potřebné údaje. Do Londýna, svého posledního působiště, dorazil 29. 3. 1939. Víme také, že v exilu spolupracoval s Československým červeným křížem a Studijním ústavem ministerstva pro národní obnovu. Konce války se však nedožil, 13. 11. 1944 zemřel jako svobodný mládenec.

Löwy mimo jiné sledoval problém jáchymovské „hornické nemoci“ - rakoviny plic (bronchiální karcinom) - jako nemoci z povolání u pracovníků v uranovém průmyslu. Toto onemocnění se dostalo do popředí pozornosti v mezinárodním měřítku i v tehdejším Československu: roku 1926 byly epidemiologické studie provedeny mezi horníky a kontrolním vzorkem obyvatelstva v saském Schneebergu na německé straně Krušných hor. Koncem dvacátých let byla vytvořena studie rudného hornictví v Jáchymově a při pitvách 
zemřelých horníků byl tehdy zjištěn zvýšený výskyt rakoviny plic. Na mezinárodním kongresu pro nemoci z povolání, který se konal v dubnu 1929 v Lyonu, byla z podnětu Löwyho jáchymovská plicní rakovina uznána za nemoc z povolání.

Ministerstvo zdravotnictví mělo značný zájem o vytvoření oddělení pro živnostenskou hygienu a pracovní lékařství nejen na Lékařské fakultě Německé univerzity v Praze, ale i obdobné poradny na Lékařské fakultě Karlovy univerzity. Tato poradna byla skutečně zrrízena v roce 1935 při II. interní klinice, v jejímž čele stál profesor Josef Pelnář. Poradnu vedl tehdejší asistent kliniky MUDr. Jaroslav Teisinger (1902-1988).

Doktorem všeobecného lékařství byl Teisinger promován v roce 1927, o deset let později se habilitoval v oboru patologie a terapie vnitřních nemocí (habilitační práce se týkala nové mikropolarografické metody ke kvantitativnímu stanovení výskytu olova). Byl členem sekce pro průmyslové lékařství při Spolku českých lékařů, v roce 1936 byl jmenován podobně jako Löwy členem kuratoria Masarykova fondu pro horníky při ministerstvu veřejných prací. Poradnu či ambulance pro nemoci z povolání zřízené při II. interní klinice LF UK vedl až do května 1945. V roce 1952 se potom stal přednostou nově založené kliniky nemocí z povolání na LF UK. Ve svých pracích věnoval pozornost hlavně průmyslovým otravám, v první řadě olovem a benzenem. K identifikaci malých množství těchto látek vypracoval se spolupracovníky mikrochemické metody s využitím již zmíněné polarografie. Jako jeden z prvních v Československu věnoval pozornost otázkám hygieny záření.

Jaroslav Teisinger měl velkou zásluhu na zřizování ústavů pracovního lékařství v českých zemích a zejména na vybudování kvalitního ústředního ústavu v Praze. Vznikla sít oddělení nemocí z povolání nebo odborů hygieny práce krajských hygienicko-epidemiologických stanic. (Podrobně viz Pazderová-Vejlupková, Jana a kol. [2005].)

\section{Textilní výroba etnograficky}

Etnografie dovoluje přistoupit ke studiu nižších tříd z pohledu jejich způsobu života a kultury, především se zaměřením na bydlení a stravování, popřípadě cestování nebo chození za prací. Může se tu objevit i vztah města a vesnice; tyto předpoklady lze doložit mimo jiné na oblasti textilní výroby. K této problematice fundovaně přistupovala česká etnografka Jarmila Štastná [1970; 1980], která podnikala terénní výzkumy a studovala archivní prameny tradiční kultury mimo jiné na Náchodsku, Ústecku a Českotřebovsku. Svou práci omezovala obdobím od osmdesátých let 19. století do první světové války, a to proto, že $\mathrm{v}$ průběhu právě těchto let se uskutečňoval přechod od domácké ruční tkalcovské práce $\mathrm{k}$ výrobě tovární. $\mathrm{K}$ tomu patří též vliv industrializace na způsob života a kulturu obyvatelstva těchto oblastí. Badatelka dále věnovala značnou pozornost sociální diferenciaci obyvatelstva, dějinám domácké výroby (postavení ručních tkalců), jakož i teritoriálnímu a sociálnímu původu továrního dělnictva.

Obecně vzato na Náchodsku i v celém podhůří Krkonoš a Orlických hor se zaměstnávalo vysoké procento obyvatelstva předením a tkaním lněné př́ize a plátna (zejména od druhé poloviny 18. století, kdy bylo plátenictví ze strany vlád velice podporováno). A tak ruční přadláci a tkalci zpracovávali podomáckým způsobem len, převážně z domácí produkce. Pracovali nejen pro vlastní potřebu, ale především pro trh domácí, zahraniční, evropský i zámořský. V podstatě však byli drobní výrobci zcela závislí na podnikavých jednotlivcích i podnikatelských společnostech, kteří měli v rukou obchod s přízí a plátnem. 
Výstižně se bydlením továrního textilního dělnictva $\mathrm{v}$ tomto mikroregionu zabýval etnograf Lubomír Procházka [1987: 283-284]: „Z forem dělnického bydlení, doložených z ostatních území Čech, byly v České Skalici nejvíce rozšířeny kolonie a nouzová obydlí, v nepoměrně menší míře pak nájemní domy obývané dělnictvem a dělnické rodinné domky. Uplatňovalo se zde také bydlení v nájmu u městských řemeslníků a živnostníků. Při výzkumu byla hlavní pozornost zaměřena na sociální otázky dělnického bydlení, na interiér, funkčnost jednotlivých prostor obydlí a bytových poměrů $\mathrm{k}$ sociálnímu a profesnímu zařazení jeho obyvatel.“

Právě uvedený mikroregion Českoskalicka měl tehdy zemědělský ráz; shora zmíněný badatel [1987: 284] dále pokračoval takto: „V České Skalici a v př́městské obci Malé Skalici, kde byly rovněž textilní provozy, bydleli dvě třetiny textilních dělníků. Menši část dělníků (tedy asi třetina zaměstnaných $\mathrm{v}$ textilních továrnách) bydlela v okolních obcích ve vlastních domech či v nájmu u chalupníků (domkářù) a docházela denně do zaměstnání do České Skalice, a to i ze vzdálenosti až $10 \mathrm{~km}$.“

Dominující formou kolektivního bydlení tu byly dělnické kolonie a nouzová obydlí, $\mathrm{z}$ individuálních typů ( $\mathrm{v}$ př́padě lépe situovaných dělníků) pak šlo o bydlení $\mathrm{v}$ rodinných domcích. Ve dvacátých letech se projevovala krize $\mathrm{v}$ bytových poměrech a dělnickém bydlení. Nejrozšířenější způsob bydlení dělnictva v České Skalici představovaly dělnické kolonie, což Lubomír Procházka [1987: 287] vysvětloval následovně: „V dělnických domcích bydleli čtyři rodiny v př́zemí a dvě rodiny v patře (v podkrovních místnostech). Byty měly vchod ze společné chodby. $V$ každé místnosti byla umístěna kachlová kamna na vaření a na zimu se ještě dle potřeby instalovala malá kamínka. Zařízení dělnických bytů se nejčastěji skládalo ze dvou postelí, almary, stolu a židlí. Dělnické ani mistrovské domky nebyly podsklepeny, měly však půdu a pod schody, ve společné síni, odkud byl vstup do podkroví, se nacházel malý sklípek na brambory. Původně byly bez sociálního zařízení a kanalizace. Až v roce 1940 byl $\mathrm{k}$ původnímu půdorysu přistavěn splachovací záchod a koupelna, dále zbudovaná malá komora na uskladnění potravin a též dřevník. (...) Vodovod byl do každého domku zaveden až v 60. letech (dřive sloužila jedna pumpa celé kolonii)."Samozřejmě mistrům a úředníkům byla přidělena obydlí vybavenější. Město v prvé řadě postavilo roku 1921 dva činžovní domy s velmi dobrým sociálním př́slušenstvím - každý tento dům měl 11 bytů různých velikostí. Další formu dělnického bydlení představuje vagónová kolonie s př́ípadnou možností úpravy a príistavby.

\section{Rozvoj technokratických tendencí}

V první polovině 20. století se poměrně hodně psalo o technokracii jako technikách umožňujících změnit tvářnost hospodářství. Jak již bylo uvedeno, velmi tu zapůsobila americká technokracie, podle níž je nutno hospodářství zdokonalit tak, že je nejprve třeba ekonomiku změřit, zjistit daný stav. Nalézt metody, jimiž by se provedla nejlepší syntéza možností, přičemž základem je požadavek odbornosti.

Vlastním původcem zásad technokracie byl údajně sociology a národohospodář Thorstein Veblen (The Engineers and the Price System, 1921). Podle něho technokracie vyjadřuje potřebu vlády odborného tvoření a v širším slova smyslu tedy vládu odborníkủ a techniků. V takových souvislostech mají největší význam technologové, tj. odborníci seznámení se zpracováním surovin a postupy ve výrobě. Dále prý o úspěchu rozhoduje také stroj, který 
člověka téměř zcela nahrazuje; do hry tak vstupuje technologický determinismus. Jinými slovy projekt technokracie předpokládal a vyžadoval unifikaci hmotných stránek zpơsobu života, podřízení se účelnosti a minimalizaci výrobních nákladů.

Setkáváme se však rovněž se „stavebnickým“ modelem technokratismu. ${ }^{2} \mathrm{~V}$ rámci tohoto specifického modelu se projevovaly př́slušné tendence hlavně v bytové kultuře dvacátých a třicátých let. K tomu se velmi nápaditě vyjádřil historik Martin Franc, v úvodu jehož studie se mimo jiné čte toto: „Měštanský byt v podobě typické pro druhou polovinu devatenáctého století nemohl vyhovovat požadavkům nové doby, která začala více doceňovat význam zdravého bydlení pro celkové zdraví společnosti. Př́liš velký počet předmětů a přemíra nesnadně čistitelných ozdob a textilií významně zhoršovaly hygienické poměry v bytech postrádajících většinou jakékoliv sociální zařízení. Obvykle tmavé a špatně větratelné pokoje vyžadovaly časově i fyzicky náročnou údržbu, protože byt kvưli nadměrné reprezentativnosti neposkytoval nijak vysokou míru komfortu. Hlavním účelem bytu bylo často spíše než pohodlné bydlení zdání přepychu. “ 3

Na začátku 20. století se postupně objevily tendence překonávající neuspokojivý stav bydlení, a proto i někteří představitelé secese navrhovali nové interiéry. Většinou se ovšem jednalo o luxusní byty a vily, u nichž se počítalo s větším komfortem. Stranou nezůstávaly estetické názory o znovuobjevení krásy čistých, jednoduchých ploch a tvarů. Zmíněný Martin Franc [1999: 177-178] má v tomto směru tento názor: „První světová válka a následující převratná léta s sebou přinesly zásadní společenské změny, které se projevily mj. i v kultuře bydlení. Mezi hlavní hnací prvky mưžeme počítat především emancipaci, s ní spojený růst zaměstnanosti žen a rychlý pokrok věd a techniky. Významnou roli zde sehrály i proměny společenské struktury, které vyvolávaly naléhavou potřebu zajištění důstojného bydlení nejširším vrstvám a zároveň přispívaly k jistému prostorovému omezení bytů vrstev středních a k poklesu počtu služebných v domácnostech. Jako další faktor můžeme uvést celkové zrychlení životního stylu."

Právě v této době nastupovala architektonická avantgarda, přičemž technokratické rysy vykazuje zejména tzv. teorie minimálního bytu. Toto pojetí bydlení bylo součástí širšího architektonického směru funkcionalismu a konstruktivismu. Dále se akcent kladl na účelnost a ekonomičnost staveb a jejich vybavení - možno říci, že jde o kontinuitu směřující od moderny z přelomu století až k purismu z počátku dvacátých let. ${ }^{4}$ Zároveň nastupuje otázka nejmenšího bytu, který by byl ještě cenově dostupný pro nejnižší společenské vrstvy; podobné úvahy reprezentují i sociální problematiku bydlení.

Debata o nejmenším bytě se v našich podmínkách odehrávala v okruhu tzv. vědeckých funkcionalistů, což byla levicová skupina kolem teoretika umění Karla Teigeho ${ }^{5}$ a architekta Jiř́ho Krohy. Důraz byl přitom položen na sociologické analýzy bydlení spojené s rozbory reálného pohybu v bytě. Suma sumárum - úvahy o ideálním bydlení budoucnosti představují vlastně proces vytváření možných světů. $V$ tomto směru nelze zapomenout ani na proslulého architekta Le Corbusiera.

Viz Pechar, Josef - Urlich, Petr, c.d.

Technokratické tendence v bytové kultuře 20. a 30. let 20. století. In. Janko, Jan - Těšínská, Emilie (ed.), c.d., s. 177-195.

4 Viz Švácha, Rostislav [1985]. Od moderny k funkcionalismu. Praha: Odeon.

5 Teige, Karel [1932]. Nejmenší byt. Praha: Nakl. Václav Petr. 
Dvacátá a třicátá léta byla i ve znamení výstav, různých architektonických prohlášení, manifestů a programových platforem architektů, zprostředkovaných řadou architektonických časopisů. Jednalo se v nich o stavby měst a nových čtvrtí se zřetelem k funkcionalistickým trendům. Architekti se rovněž setkávali na sjezdech a konferencích, nebot' usilovali o nové pojetí architektury, prostředí a života, včetně etického a estetického řádu. V podobných projevech vynikal mimo jiné Jiř́i Kroha, dále se angažoval i Josef Gočár, Karel Honzík, Oldřich Starý a další, kteří taktéž přetvářeli zahraniční impulsy. ${ }^{6}$

$\mathrm{V}$ popředí pozornosti se nacházely veřejné budovy, nájemní domy s byty, stejně jako typové rodinné domy a vily v různých částech či čtvrtích (Velké) Prahy. Nabízí se otázka, o co šlo funkcionalismu právě v bytové kultuře. Vzhled nebyl ani tolik určován estetickými hledisky, nýbrž hlavně těmi funkčními. Své místo tu měla i hygiena v podobě vlastního sociálního zařízení (WC, koupelny nebo jen sprchy), nehledě na řádné přirozené osvětlení bytu a jeho přijatelnou větratelnost. Do hry samozřejmě vstupuje též funkcionalistická minimalizace věcí ve všech místnostech. Nábytek měl být maximálně hygienický a účelný, také lehký apod. Předpokládaná standardizace souvisela se sériovou výrobou bytových součástí i celých domů; prostorovou úspornost měl zajištovat sklopný a skládací nábytek (stoly, postele...), uplatňovaly se nové materiály a barvy.

Měly to být ženy, kdo se stane tvůrcem nové domácnosti - chystá se éra „hospodyňské racionalizace“ a zefektivění ženské práce. Kuchyně má být vybavena dřezem s tekutou studenou a teplou vodou, stejná racionalizace se vázala i na kuchyňský nábytek, přičemž nemuselo jít hned o obytnou kuchyň. Úložný prostor se zvětšoval pomocí vestavěných skříní. Není nepř́ípadné se zeptat, jak to bylo s chlazením ve spíži, respektive s chladničkami, které se v Americe objevily na začátku dvacátých let.

Speciální aspekty se týkají bydlení v Praze, kde do celého procesu vstupují stavitelé, ale především profesionální architekti projektující byty a domky hlavně pro střední vrstvy obyvatelstva. Důraz je kladen rovněž na umělecká řemesla a průmyslové výtvarnictví; svými důmyslnými projekty zkrátka architekti usilovali změnit tvář (hlavního) města. Stranou nezůstávaly ani koncepčně vybavené interiéry opatřené nápaditým nábytkem a drobnými uměleckými předměty. ${ }^{7}$ Ve správném interiéru tehdejšího stylu nesměly chybět univerzální židle značky Thonet.

Pro zajímavost uved’me, že již na začátku dvacátých let se operuje s pojmem „design“ nebo „designer“. Koncentrovaně se k této problematice vyjádřil Karel Honzík [1946: 207]: „Je možno považovat za př́íznačné, že se právě v Americe a v Anglii vynořil v posledních desetiletích nový průmyslový odborník, kterého nazývají ,industrial designer, jehož úkolem je věnovat se výhradně návrhu průmyslových předmětů (industrial design). Každý výrobek, jehož konstruktivní stránka byla zhruba vyřešena, přijde nakonec do atelieru takového projektanta, který si pohrává s jeho obrysem, s jeho liniemi, aby mu dal ušlechtilý tvar. Že nejde o to navěšovat na věci zbytečné ornamenty, nýbrž o nejlepší a harmonický výraz účelné skladby, o volbu úhledných materiálů, to dokazuje řada amerických výrobkù, které přicházely i k nám a byly s to konkurovat se zdejšími výrobky: lednice, umyvadla, auta, kuchyňské nářadí, atd.“

\footnotetext{
Viz Švácha, Rostislav, c.d., s. 54-55.

Viz např́íklad Adlerová, Alena [1983]. České užité umění 1918-1938. Praha: Odeon.
} 
Dále se zdůrazňuje péče o estetickou stránku paralelně s hlediskem účelovým a harmonizačním, které lze opřít o nauku o rytmu, proporcích a zlatém řezu. Vlastně se dá říci, že jde o přirozený sklon. Jinak „průmyslový architekt“ byl ochotně zařazován do výroby a využíván například při stavbě strojů. Původně mohl být exponován jako kreslír, malíř, illustrátor, elektroinženýr apod., ale přeškolil se, adaptoval podle vznikající materiální potřeby, když vyvstala ta správná chvíle.

\section{Závěr - Na co se nedostalo}

Na závěr se pokusme v duchu celé studie naskicovat určité další možnosti, které ale nemusí ve všem plně odpovídat předchozím úvahám. Pomysleme například na to, jak velká hospodářská krize kolem roku 1930 přináší pro Evropany značné vystřízlivění z původně nadějného uspořádání světa na principu taylorismu a fordismu. Spisovatelé a novináři najednou před sebou vidí člověka uměle vycvičeného, přeměněného na pouhý pracovní nástroj. Představy o domnělém světě blahobytu a štěstí tak třeba reportér Egon Erwin Kisch označoval za mýtus. Úskalí pásové výroby zachycuje Kisch ve své knize Americký ráj z roku 1930. Autorovy komentáře by rozhodně stály za bližší pozornost i v současné době.

Neustálé kalkulace a úzkostlivé měření času se kritikům a samotným aktérům výroby jeví stále více jako deprimující. S technickou racionalizací se počítalo rovněž při těžbě uhlí, ovšem nejen v továrnách a dolech, také kancelářích vše muselo běžet na plné obrátky práci tu oživily psací stroje. Podle starších českých filmů by snad bylo možné zrekonstruovat pravděpodobné uspořádání kanceláří plných pracovních stolů sekretářek, neklidně přecházejících úředníků a strojového klapotu...

V našich úvahách se nedostalo ani na fungování pavlačových bytů, jež byly tradičně $\mathrm{k}$ dispozici v některých čtvrtích Prahy a dalších měst. Pomineme též detailnější průzkum zásadního významu nejrůznějších výstav při získávání nových inspirací pro pracovní a bytové poměry (například Světová výstava v Londýně, pořádaná roku 1851). Invenční výstavy ostatně probíhají již od konce 18. století. Stranou zůstanou rychlé změny prodejního prostředí (role prodavaček a prodavačů), o nichž se také lze mnohé dozvědět z dobových filmů zobrazujících vedle klasických trhů i nové obchodní domy (například Brouk a Babka).

\section{Literatura}

Adlerová, Alena [1983]. České užité umění 1918-1938. Praha: Odeon.

Borscheid, Peter [2007]. Virus času. Praha: Mladá fronta.

Čech, Vladimír - Joukl, Eduard [1969]. „Dělnická otázka“ a počátky naší sociologie průmyslového podniku. Sociologický časopis 5 (3): 284-293.

Honzík, Karel [1946]. Tvorba životního slohu. Stati o architektuře a užitkové tvorbě vůbec. Praha: Václav Petr.

Hubatová-Vacková, Lada - Pachmanová Martina - Pečinková, Pavla [2014]. Věci a slova. Umělecký průmysl, užité umění a design v české teorii a kritice 1870-1970. Praha: UMPRUM.

Chalupný, Emanuel [1941]. Práce a jiné činnosti. Praha: vlastní náklad.

Chase, Stuart [1931]. Člověk a stroj. Praha: Jan Laichter. 
Janko, Jan - Těšínská, Emilie (ed.) [1999]. Technokracie v českých zemích (1900-1950). Praha: Archiv AV ČR - Institut základů vzdělanosti, společné pracoviště UK a AV ČR.

Pazderová-Vejlupková, Jana a kol. [2005]. Profesor Jaroslav Teisinger a historie českého pracovního lékařství. Praha: Galén.

Pechar, Josef - Urlich, Petr [1981]. Programy české architektury. Praha: Odeon.

Procházka, Lubomír [1984]. Formy bydlení zemědělského dělnictva v okolí České Skalice (o. Náchod). Českýlid 71 (1): 209-214.

Procházka, Lubomír [1987]. Bydlení továrního dělnictva v České Skalici. In. Kejzlar, Josef a kol. Dějiny textilní výroby v České Skalici. Sborník studií vydaný u príležitosti 150. výročí závodu Tiba 03 v České Skalici. Dvưr Králové nad Labem - Ústí nad Orlicí, s. 283-297.

Robek, Antonín - Moravcová, Mirjam - Štastná, Jarmila (ed.) [1981]. Stará dělnická Praha. Život a kultura pražských dělníků. Praha: Academia.

Špaček, Stanislav [1942]. Zdatností k úspěchu. Zpracováno podle zásad vědeckého ř́zení. Praha: Všetečka a spol.

Štastná, Jarmila [1970]. Změny ve způsobu života tkalců v procesu industrializace. Praha: Ústav pro etnografii a folkloristiku ČSAV.

Štastná, Jarmila [1977]. Stravování pražského dělnictva a chudiny ve druhé polovině 19. a na počátku 20. století. Český lid 64 (1): 9-22.

Štastná, Jarmila [1980]. Život textilních dělníků na Ústecku a Českotřebovsku 1870-1914. Vysoké Mýto: Okresní muzeum.

Švácha, Rostislav [1985]. Od moderny k funkcionalismu. Praha: Odeon.

Těšínská, Emilie [2017]. Profesor MUDr. Julius Löwy (1885-1944), obor pracovního lékařství na Pražské německé univerzitě a problematika nemocí z povolání v meziválečném Československu. Acta Universitatis Carolinae - Historia Universitatis Carolinae Pragensis LVII (1): 35-80.

Turková, Miloslava [1988]. Úroveň bydlení čelákovických kovodělníků v době první republiky. Český lid 75 (1): 142-150.

Verunáč, Václav a kol. (ed.) [1934]. Encyklopedie výkonnosti, sv. 1 Člověk. Praha: Sfinx - B. Janda.

Bohuslav Šalanda působí na Pracovišti historické sociologie Fakulty humanitních studií Univerzity Karlovy. Odborně se zabývá sociologickými a etnologickými výzkumy lokálních společenství v mikroregionu východních Čech, přičemž mimo jiné sleduje limity a možnosti každodenních a herních aktivit. V poslední době se zaměruje na studium automobility. 